\title{
The Potential Re-Use of Saudi Mine Tailings in Mine Backfill: A Path towards Sustainable Mining in Saudi Arabia
}

\author{
Mohammed Hefni *(D, Hussin A. M. Ahmed (D, Ebaa Shaikh Omar and Maaz A. Ali (D) \\ Mining Engineering Department, King Abdulaziz University, Jeddah 21589, Saudi Arabia; \\ haahmed@kau.edu.sa (H.A.M.A.); eshaikhomar@stu.kau.edu.sa (E.S.O.); \\ mnoureldaimali@stu.kau.edu.sa (M.A.A.) \\ * Correspondence: mhefni@kau.edu.sa; Tel.: +966-599993053
}

Citation: Hefni, M.; Ahmed, H.A.M.; Omar, E.S.; Ali, M.A. The Potential Re-Use of Saudi Mine Tailings in

Mine Backfill: A Path towards

Sustainable Mining in Saudi Arabia. Sustainability 2021, 13, 6204. https:// doi.org/10.3390/su13116204

Academic Editors: Jutta Gutberlet, Sayed Mohammad Nazim Uddin and Adam Smoliński

Received: 31 March 2021

Accepted: 28 May 2021

Published: 31 May 2021

Publisher's Note: MDPI stays neutral with regard to jurisdictional claims in published maps and institutional affiliations.

Copyright: (c) 2021 by the authors. Licensee MDPI, Basel, Switzerland. This article is an open access article distributed under the terms and conditions of the Creative Commons Attribution (CC BY) license (https:/ / creativecommons.org/licenses/by/ $4.0 /)$.

\begin{abstract}
The Kingdom of Saudi Arabia covers an area of approximately 2 million $\mathrm{km}^{2}$ and is rich in natural resources that are necessary for industrial development. The estimated mineral wealth beneath the Kingdom's soil is approximately USD 1.33 trillion, as reported by the Ministry of Industry and Mineral Resources. The Kingdom's vision for 2030 is to develop the mining sector to become the third pillar of the domestic economy. Therefore, exploration and mining activities are expected to accelerate over the next decade, which will lead to increased waste production. New executive regulations issued in January 2021 contain several sustainable elements related to the environment, social responsibility, and occupational health and safety. Therefore, this study aims to promote an example of sustainable mining activities in the Kingdom that could be adapted to meet the regulatory requirements. Cemented paste backfill samples of varying composition were made with waste materials from a Saudi copper mine for re-injection into underground mining cavities to minimize waste exposure to the environment. The samples were tested for unconfined compressive strength (UCS) after 7, 14, 28, 56, and 90 days of curing. Results from a statistically designed experiment technique show that the samples developed sufficient strength to be used in mine backfilling applications. Strong negative relationships were detected between the UCS and the water-to-binder ratio. There is strong potential for mine backfill technology to be applied to a wide range of Saudi Arabian mines to enhance the sustainability of the mining sector.
\end{abstract}

Keywords: backfill; pozzolans; cement; compressive strength; tailings

\section{Introduction}

Mine tailings are waste products from mineral processing operations that either contain no valuable minerals or contain valuable minerals that are not economically feasible to recover [1-4]. The tailings' composition depends on the nature of the processed ores and the separation techniques adopted [5-8]. Typically, tailings are in the form of fine gangue particles ranging from 1 to $600 \mu \mathrm{m}$ in size and mixed with process water and (sometimes) chemical reagents [9-11]. These are discharged as slurries into lagoons or tailings ponds at the mine site to permit the gravity separation of wastewater from solids. To reduce freshwater consumption for mineral processing, solids-free wastewater may be recycled to operations, whereas the solids are often discarded $[7,12,13]$. Therefore, solid waste accumulates over the life of the mine, and the management of it poses many challenges in terms of storage, stability, and safety, in addition to the negative environmental impacts [14]. Globally, mine tailings are produced at a rate of 5-14 billion tonnes/year. In copper and most metal ore mining operations, approximately $95-99 \%$ of processed ore may be rejected as tailings [5,9]. This has become a global concern as reflected in the intense research interest: between 1988 and 2017, more than 3500 peer-reviewed articles were published that focused on mine waste management. Most were authored by researchers from the USA, Canada, Spain, Australia, and China [15-17]. Apart from challenges related to storing mine 
tailings, soil contamination, and ground and surface water contamination, catastrophic storage facility failures have caused human fatalities [18-21].

Effective tailings management will help the mining sector transition to a sustainability framework, which is particularly critical since mining involves the exploitation of finite resources. In the minerals industry, sustainability can be approached from two perspectives, with the second building upon the first. One is focused on sustainable resource use and management during operations (i.e., sustainable functioning as described by [22]), and the other is focused on minimizing the social and environmental impacts of the mining project during and after operations (i.e., sustainable development as described by [22,23]). These concepts have been more broadly developed in industries that use renewable resources (e.g., the fashion industry [24]). However, few studies have included sustainability metrics in techno-economic assessments of mining projects from the design phase through to product marketing and sales.

Various tailings management methods have been employed at modern mines worldwide to limit finite resource consumption and prevent environmental pollution [25-27]. For example, solid tailings have been used to fabricate bricks, ceramic tiles, mortars, alkaliactivated materials, geopolymers, and mine backfill [28-33]. As a means to re-use materials, tailings have been used in backfill at the industrial scale as an ingredient in paste backfill for underground mines [34-38]. The re-use of tailings in mine backfill also reduces the cost of mining waste disposal in dumps [39]. Optimizing backfill systems from preparation to placement while considering capital, operating, and maintenance costs is critical to supporting a sustainable mining operation. Poor backfill system design can drive up costs and jeopardize the safety of the working environment.

Mine backfilling involves filling voids that were created during underground excavations to provide ground support to the underground environment. Mine backfill is typically made with tailings mixed with a suitable binder-usually Portland cement (PC). The cost of cement can account for up to $75 \%$ of backfill costs [31,34]. Therefore, artificial (e.g., fly ash and slags) and natural pozzolans (e.g., pumice and volcanic ash) are added to cemented paste backfill (CPB) to partially replace cement $[31,32,40]$. The mining method determines the $\mathrm{CPB}$ mixture design and the target unconfined compressive strength (UCS). For example, room and pillar mining requires UCS values of 5-7 MPa, whereas in cut and fill mining, a UCS of $1 \mathrm{MPa}$ is sufficient. The UCS required for CPB can be lower than $1 \mathrm{MPa}$ if it will be used for free-standing applications [41].

The physical and chemical properties of binders and tailings affect CPB strength $[32,33,42]$. For example, replacing $20 \%$ of PC in CPB with the natural pozzolan zeolite resulted in a higher UCS (0.66 MPa) after 56 days of curing relative to reference samples prepared with PC (0.50 MPa) [43]. Replacing PC with $10,25,30$, and $35 \%$ clay pozzolan improved $\mathrm{CPB}$ strength to $287,280,268$, and $268 \mathrm{kPa}$, respectively, relative to CPB made with ordinary PC (264 kPa), after 56 days of curing [44,45]. Tailings containing sulfide minerals such as pyrite $\left(\mathrm{FeS}_{2}\right)$ may lose UCS over the long term if general use cement is used [46]. Therefore, cement is partially replaced by pozzolans in backfill to mitigate sulfate attack [46,47].

The 2030 vision of the Kingdom of Saudi Arabia is to develop the mining sector to become the third pillar of its gross domestic product. Therefore, exploration and mining activities are expected to accelerate over the next decade, which will lead to increased waste production. Despite the high volume of accumulated tailings and immense pozzolan resources in Saudi Arabia, no study has yet investigated their suitability to mine backfilling applications. In order to support the efforts to develop sustainable mining practices in Saudi Arabia and to comply with the revised Saudi mining regulations, this study aims to investigate the feasibility of re-using tailings and using pozzolanic materials in mine backfill. Furthermore, the optimum backfill design was determined in terms of the effect of the water-to-binder ratio on UCS. A detailed techno-economic assessment (e.g., [22]) is beyond the scope of this paper. Rather, the goal is to provide empirical data and a 
modeling approach to quantify one of many possible techniques to contribute to building a sustainability framework within the mining sector.

Tailings provided by a copper mine in Saudi Arabia and two types of pozzolanic cement were used to prepare backfill samples. Pozzolanic cement was chosen because it is less expensive than ordinary PC, and it may mitigate sulfate attack arising from pyrite in the tailings. Sulfuric acid produced from the oxidation of sulfide tailings can release toxic heavy metals that can negatively affect surface and ground water [48]. Therefore, the safe disposal of such materials in underground voids through backfilling would help to mitigate the negative environmental impacts. In addition, the use of pozzolans can contribute to minimizing cement usage, thus lowering $\mathrm{CO}_{2}$ emissions from cement production [49-52].

The UCS was measured on CPB samples cured for $7,14,28,56$, and 90 days. Results were analyzed using the response surface methodology (RSM), a designed experiment technique, with a mixture that was designed to best understand the effects of the investigated factors on UCS development. Hefni and Hassani used RSM to investigate the effects of binder dosage, air entrainment, and their interactions on backfill UCS and density [53]. Other researchers have used RSM to develop predictive models for backfill properties such as UCS, slump, solids concentration, and cost [54].

The paper is structured into six sections. After the "Introduction", the "Experimental Materials" section explains the chemical and physical characterization of the materials used to prepare CPB samples. The "Experimental Design" section describes the design of the $\mathrm{CPB}$ sample mixtures, the preparation of the $\mathrm{CPB}$ samples, and the UCS testing procedures that were employed. The "Results and Discussion" section presents and discusses the most significant experimental findings. Moreover, it interprets key study results in the context of practical application and previous research. The "Policy Implications" section describes how the study findings could contribute to sustainable mining policies in Saudi Arabia. The "Conclusions" section focuses on future work and emphasizes the importance and potential role of mine backfilling in sustainability in the mining sector in Saudi Arabia.

\section{Experimental Materials}

2.1. Tailings

Tailings from a copper mine in Saudi Arabia were measured for particle size distribution by laser diffraction (Figure 1). The cumulative passing at 10, 30, 50, 60, and $90 \mu \mathrm{m}$ diameters, specific gravity (SG), uniformity coefficient $\left(C_{u}\right)$, and curvature coefficient $\left(C_{c}\right)$ are summarized in Table 1 . The two coefficients indicate that the tailings are poorly graded per the Unified Soil Classification System.

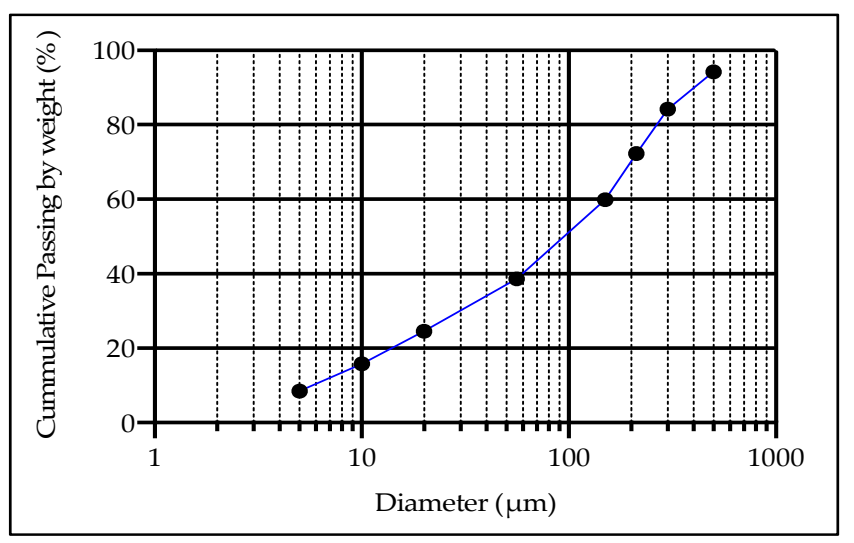

Figure 1. Particle size distribution of the study copper tailings. 
Table 1. Physical properties of the study tailings.

\begin{tabular}{|c|c|c|c|c|c|c|c|}
\hline \multicolumn{5}{|c|}{ Cumulative Passing (wt.\%) } & \multirow[t]{2}{*}{ SG } & \multirow[t]{2}{*}{$\mathrm{C}_{\mathrm{u}}{ }^{1}$} & \multirow[t]{2}{*}{$\mathrm{C}_{\mathrm{c}}{ }^{2}$} \\
\hline $\mathrm{D}_{10}$ & $\mathrm{D}_{30}$ & $\mathrm{D}_{50}$ & $\mathrm{D}_{60}$ & $\mathrm{D}_{90}$ & & & \\
\hline 14.70 & 29.91 & 36.89 & 40.04 & 48.69 & 2.95 & 2.72 & 1.52 \\
\hline
\end{tabular}

X-ray fluorescence analysis showed that $\mathrm{Si}, \mathrm{Fe}, \mathrm{Al}, \mathrm{Mg}, \mathrm{Ca}$, and $\mathrm{S}$ were major components of the tailings, and $\mathrm{Na}, \mathrm{Ni}, \mathrm{K}, \mathrm{Cu}$, and $\mathrm{Cr}$ were minor components (Table 2). These results are supported by peaks in the X-ray diffraction pattern of the tailings scanned at $2 \theta$ from 10 to 110 degrees with an increment of 0.1 , which indicates the presence of chlorite, quartz, nickel dioxide, pyrite, kaliophilite, periclase, and albite (Figure 2). The tailings contain sulfides in the form of pyrite, which can negatively affect backfill physical properties, as noted above.

Table 2. X-ray fluorescence results of the study tailings expressed as oxides.

\begin{tabular}{ccccccccccc}
\hline $\mathrm{SiO}_{\mathbf{2}}$ & $\mathbf{F e O}$ & $\mathrm{Al}_{2} \mathrm{O}_{3}$ & $\mathrm{SO}_{3}$ & $\mathbf{M g O}$ & $\mathrm{CaO}$ & $\mathbf{N a}_{\mathbf{2}} \mathrm{O}$ & $\mathrm{NiO}$ & $\mathbf{K}_{\mathbf{2}} \mathrm{O}$ & $\mathrm{Cu}$ & $\mathrm{Cr}_{2} \mathrm{O}_{3}$ \\
\hline 49.78 & 13.89 & 11.97 & 9.55 & 9.13 & 3.89 & 0.90 & 0.27 & 0.25 & 0.23 & 0.13 \\
\hline
\end{tabular}

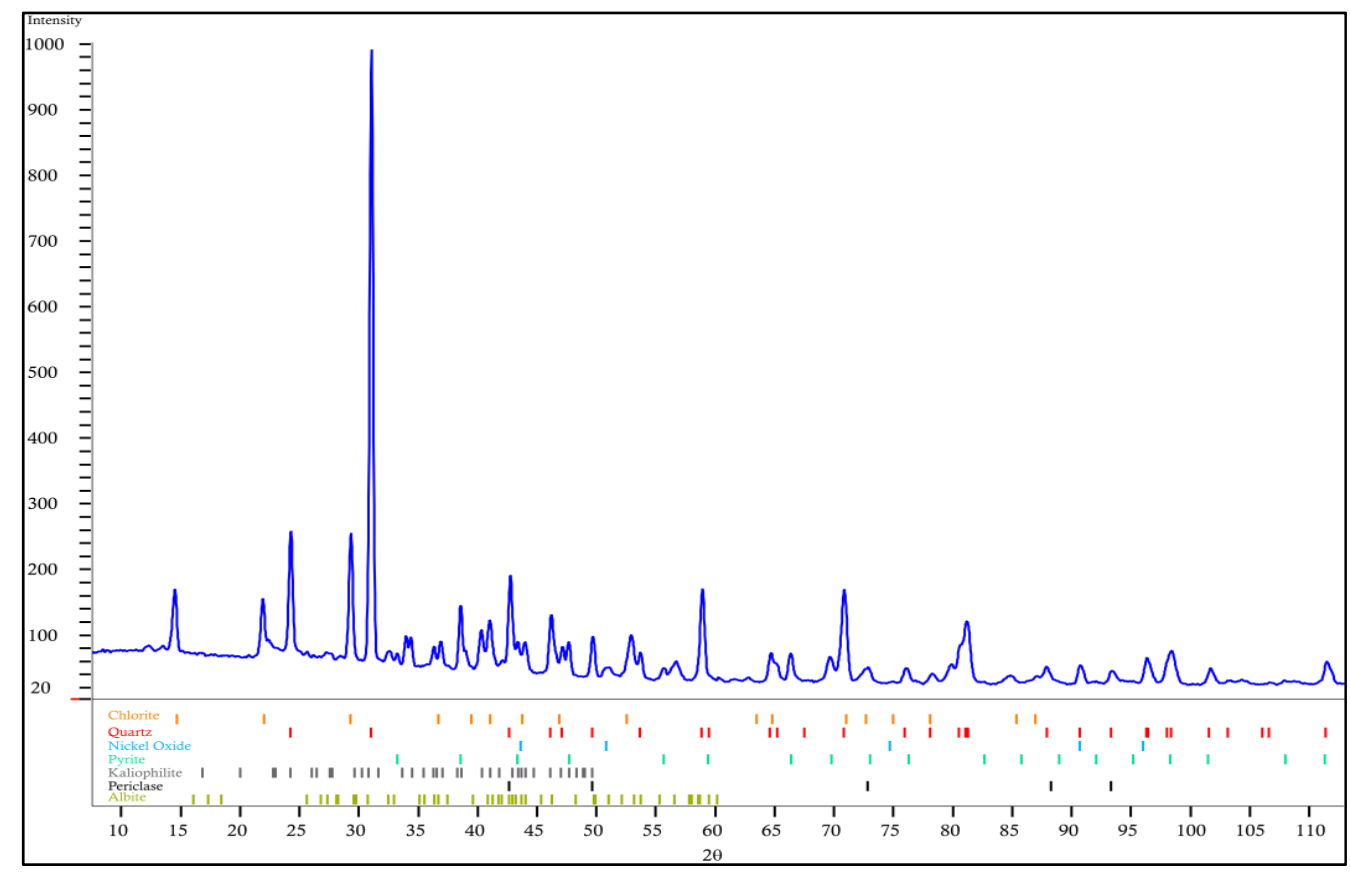

Figure 2. X-ray diffraction patterns showing mineral phases of the copper tailings.

\subsection{Water}

Water is mixed into mine backfill to facilitate transportation to underground voids and to allow cement hydration. Mine backfill can be prepared with water from a variety of sources such as lakes, municipal supplies, and processing plants $[55,56]$. Water chemistry can affect cement hydration and (or) the rheological properties of the backfill $[57,58]$. In this study, CPB samples were prepared with raw water from the processing plant at the mine site (Table 3). 
Table 3. Properties of the mixing water used to prepare cemented paste backfill samples.

\begin{tabular}{cc}
\hline Property & Value \\
\hline Appearance & Clear \\
pH @ $20^{\circ} \mathrm{C}$ & 7.4 \\
Electrical conductivity @ $25^{\circ} \mathrm{C}(\mu \mathrm{S} / \mathrm{cm})$ & 1320 \\
Total dissolved solids $(\mathrm{mg} / \mathrm{L})$ & 806 \\
Turbidity $(\mathrm{NTU})$ & 0.2 \\
Total hardness $(\mathrm{mg} / \mathrm{L})$ & 159 \\
Bicarbonate $(\mathrm{mg} / \mathrm{L})$ & 144 \\
Carbonate $(\mathrm{mg} / \mathrm{L})$ & $<1$ \\
Total alkalinity $(\mathrm{mg} / \mathrm{L} \mathrm{CaCO})$ & 118 \\
\hline
\end{tabular}

\subsection{Binders}

CPB samples were prepared with two types of Portland pozzolana cement-PPC1 and PPC2-provided by two major Saudi cement companies (Table 4). PPC1 and PPC2 have specific surface areas of 3710 and $3300 \mathrm{~cm}^{2} / \mathrm{g}$, respectively. Both contain $20 \mathrm{wt} . \%$ natural pozzolans and meet the conformity standards of the Saudi Organization for Standardization and Metrology.

Table 4. Major oxides present in the Portland pozzolana cement detected by X-ray fluorescence.

\begin{tabular}{ccc}
\hline Oxide & $\begin{array}{c}\text { PPC1 } \\
\text { (wt.\%) }\end{array}$ & $\begin{array}{c}\text { PPC2 } \\
\text { (wt.\%) }\end{array}$ \\
\hline $\mathrm{CaO}$ & 55.43 & 49.42 \\
$\mathrm{SiO}_{2}$ & 23.80 & 24.94 \\
$\mathrm{Al}_{2} \mathrm{O}_{3}$ & 5.48 & 7.52 \\
$\mathrm{Fe}_{2} \mathrm{O}_{3}$ & 5.83 & 6.49 \\
$\mathrm{MgO}_{\mathrm{SO}}$ & 4.97 & 3.31 \\
$\mathrm{~K}_{2} \mathrm{O}$ & 2.29 & 2.75 \\
$\mathrm{Na}_{2} \mathrm{O}$ & 0.34 & 0.51 \\
\hline
\end{tabular}

\section{Experimental Design}

\subsection{Mixture Design}

$\mathrm{CPB}$ mixtures were prepared with differing tailings, water, and binder contents calculated using Equations (1)-(3), respectively:

$$
\begin{aligned}
& \text { Tailings (\%) }=\frac{M_{T}}{M_{B}+M_{T}+M_{W}} \\
& \text { Water (\%) }=\frac{M_{W}}{M_{B}+M_{T}+M_{W}} \\
& \text { Binder (\%) }=\frac{M_{B}}{M_{B}+M_{T}+M_{W}}
\end{aligned}
$$

where $M_{T}, M_{W}$, and $M_{B}$ are the mass of tailings, water, and binder, respectively.

The CPB recipes were designed using Design-Expert ${ }^{\circledR}$ v12 commercial software, which offers various mixture design models, including simplex lattice, simplex centroid, axial design, and optimal (custom) design. The optimal mixture design was chosen because it has a flexible design structure to accommodate custom models and irregular (constrained) regions. Scheffé mix models were used as they can handle the natural constraints of mixture designs. The general formula for this type of model is quadratic (Equation (4)):

$$
y=b_{0}+\sum_{i=1}^{k} b_{i} x_{i}+\sum_{i=1}^{k-1} \sum_{i<j}^{k} b_{i j} x_{i} x_{j}
$$


where $y$ is the measured response (UCS), $b_{0}, b_{i}$, and $b_{i j}$ are regression coefficients, and $x_{i}$ and $x_{j}$ are the investigated factors.

The ranges of the tailings, water, and binder used as inputs in the optimal mixture design (Table 5) generated the 11 recipes in Table 6 . Note that the only difference between PPC1 and PPC2 in Table 5 is the binder lower level.

Table 5. Ranges of cemented paste backfill ingredients used in the mixture design.

\begin{tabular}{cccccc}
\hline Code & Ingredient & \multicolumn{2}{c}{ PPC1 } & \multicolumn{2}{c}{ PPC2 } \\
\hline & & Low & High & Low \\
$\mathbf{( w t . \% )}$ & $(\mathbf{w t . \% )}$ & $\begin{array}{c}\text { High } \\
\mathbf{( w t . \% )}\end{array}$ \\
\hline A & Tailings & 64.01 & 71.68 & 64.01 & 71.68 \\
B & Water & 25.85 & 27.64 & 25.85 & 27.64 \\
C & Binder & 1.57 & 8.57 & 1.62 & 8.57 \\
\hline
\end{tabular}

Table 6. Mixture compositions generated by the optimal design for cemented paste backfill samples prepared with PPC1 and PPC2 as binders; w/b: water-to-binder ratio.

\begin{tabular}{|c|c|c|c|c|c|c|c|c|}
\hline \multirow{2}{*}{ Recipe } & \multicolumn{4}{|c|}{ PPC1 } & \multicolumn{4}{|c|}{ PPC2 } \\
\hline & $\begin{array}{l}\text { Tailings } \\
\text { (wt.\%) }\end{array}$ & $\begin{array}{l}\text { Water } \\
\text { (wt.\%) }\end{array}$ & $\begin{array}{l}\text { Binder } \\
\text { (wt.\%) }\end{array}$ & $w / b$ & $\begin{array}{l}\text { Tailings } \\
\text { (wt.\%) }\end{array}$ & $\begin{array}{l}\text { Water } \\
\text { (wt.\%) }\end{array}$ & $\begin{array}{l}\text { Binder } \\
\text { (wt.\%) }\end{array}$ & $w / b$ \\
\hline 1 & 65.58 & 25.85 & 8.57 & 3.02 & 69.59 & 27.64 & 2.77 & 9.98 \\
\hline 2 & 66.93 & 25.85 & 7.22 & 3.58 & 65.44 & 27.23 & 7.33 & 3.71 \\
\hline 3 & 65.39 & 27.27 & 7.33 & 3.72 & 67.58 & 26.85 & 5.56 & 4.83 \\
\hline 4 & 66.50 & 27.64 & 5.86 & 4.72 & 68.93 & 25.85 & 5.22 & 4.95 \\
\hline 5 & 71.41 & 27.02 & 1.57 & 17.21 & 66.30 & 27.64 & 6.06 & 4.56 \\
\hline 6 & 68.23 & 27.64 & 4.13 & 6.69 & 71.68 & 26.70 & 1.62 & 16.48 \\
\hline 7 & 71.68 & 25.85 & 2.47 & 10.47 & 66.88 & 25.85 & 7.27 & 3.56 \\
\hline 8 & 67.84 & 26.60 & 5.56 & 4.78 & 70.10 & 25.85 & 4.05 & 6.38 \\
\hline 9 & 69.79 & 25.85 & 4.36 & 5.93 & 64.01 & 27.64 & 8.35 & 3.31 \\
\hline 10 & 64.01 & 27.42 & 8.57 & 3.20 & 68.25 & 27.64 & 4.11 & 6.73 \\
\hline 11 & 69.81 & 27.42 & 2.77 & 9.90 & 65.32 & 26.11 & 8.57 & 3.05 \\
\hline
\end{tabular}

\subsection{Preparation of Backfill Samples}

The $\mathrm{CPB}$ ingredients were mixed in a bucket with a handheld cement mixer to create a homogeneous paste (Figure 3a). Holes were drilled in the bottoms of plastic, cylindrical molds (50 mm diameter, $100 \mathrm{~mm}$ height) to simulate the free drainage that can occur when $\mathrm{CPB}$ is placed in underground voids (Figure $3 \mathrm{~b}$ ). The CPB was poured into the molds: an extension on the top of the molds compensated for shrinkage and maintained the height-to-diameter ratio at $\geq 2$ for UCS testing (Figure 3c). The samples were cured for $7,14,28,56$, and 90 days in a curing chamber at $95 \%$ relative humidity and $40{ }^{\circ} \mathrm{C}$ to simulate underground mine conditions (Figure 3d). Finally, CPB samples were extruded from the molds prior to UCS testing (Figure 3e). 
(a)

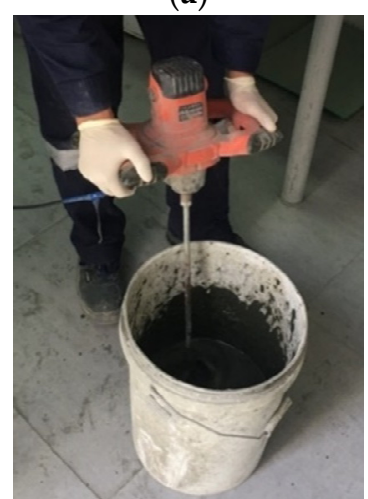

(d)

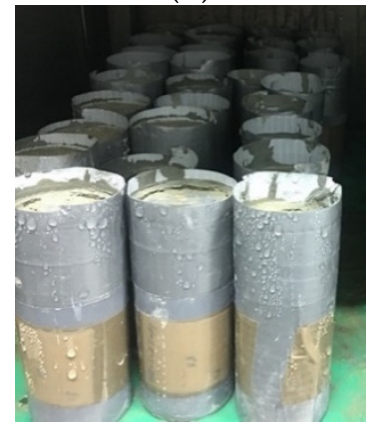

(b)

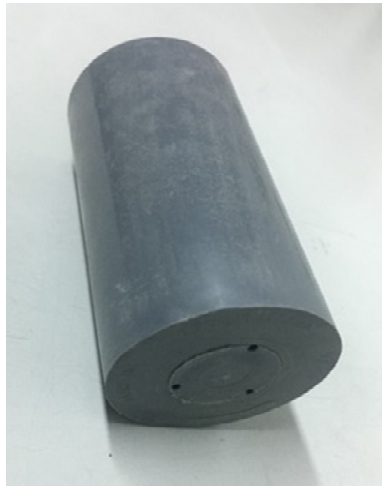

(e)

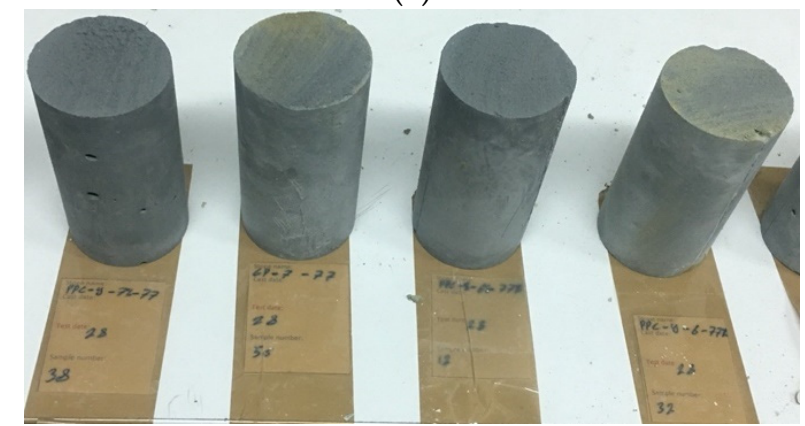

(c)

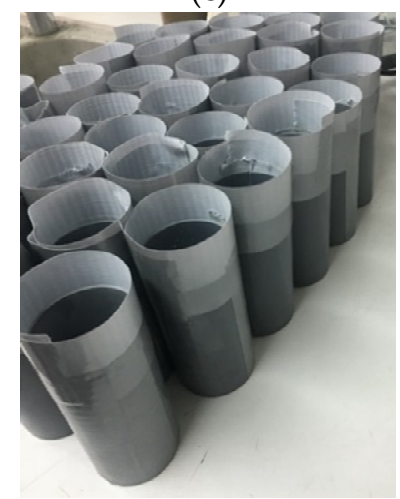

Figure 3. Preparation of cemented paste backfill samples: (a) ingredients mixed with a handheld cement mixer, (b) small holes drilled in the bottom of cylindrical molds, (c) mixtures in molds with extensions, (d) samples in curing chamber, and (e) extruded samples.

\subsection{Unconfined Compressive Strength Testing}

Duplicate CPB samples for each recipe in Table 6 were tested for UCS on each of the five curing days using a digital mechanical press (ELE Multiplex 50) with a normal loading capacity of up to $50 \mathrm{kN}$ and a displacement rate of $1 \mathrm{~mm} / \mathrm{min}$ (Figure $4 \mathrm{a}, \mathrm{b}$ ). Samples were subjected to uniaxial load until failure (Figure 4c) in accordance with ASTM D2166/D2166M-16 [59].

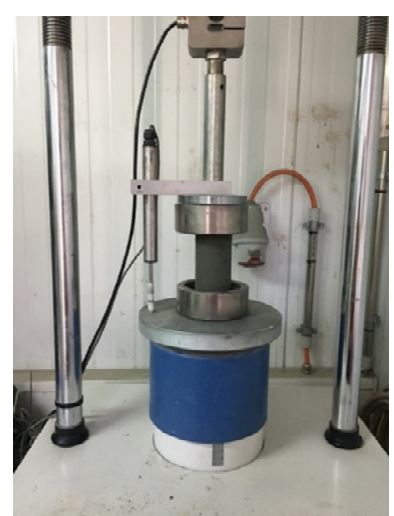

(a)

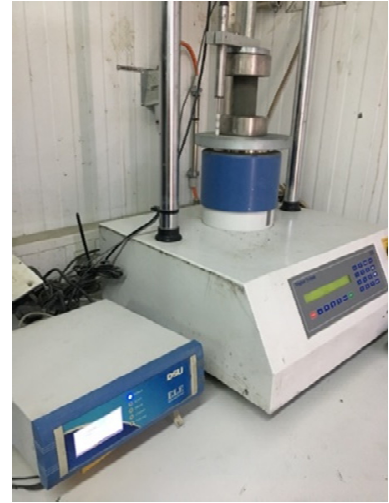

(b)

Figure 4. Cont. 


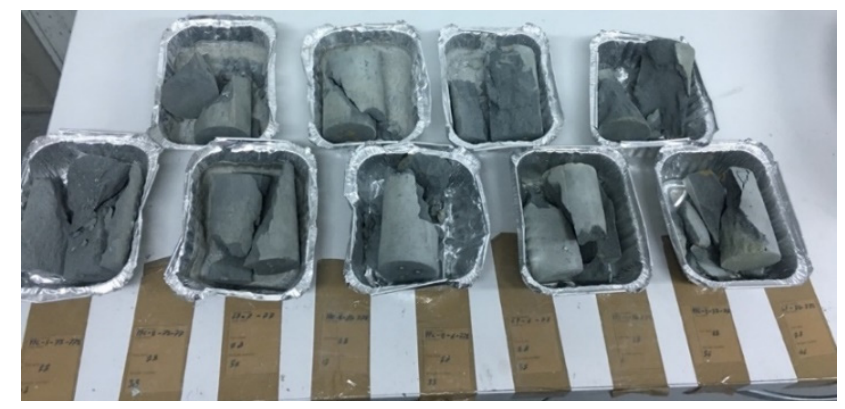

(c)

Figure 4. (a) Loading of a cemented paste backfill sample onto the ELE Multiplex 50 mechanical press, (b) sample under uniaxial load, and (c) example of sample failures after unconfined compressive strength testing.

\section{Results and Discussion}

\subsection{Interpretation of Model Output}

The mixture design ternary plots for the CPB samples prepared with PPC1 show the $\mathrm{CPB}$ compositions from Table 6 on the vertices of the triangles (Figure 5). To visualize the influence of simultaneous changes in different $\mathrm{CPB}$ components, an imaginary line can be drawn parallel to any side of the triangles on the left side of the figures moving towards the corresponding vertex. For example, when $\mathrm{CPB}$ was cured for 28 days (Figure $5 \mathrm{c}$ ), the lines parallel to side $\mathrm{AB}$ (tailings-water) moving towards vertex $\mathrm{C}$ (binder) indicate increasing binder content approaching the maximum binder content at the vertex. Following this concept, it can be seen that the UCS contours on the right side of each panel increased from $200 \mathrm{kPa}$ (low binder content) to $1200 \mathrm{kPa}$ (high binder content). This same pattern occurred regardless of curing time: UCS was higher at higher binder contents (i.e., near binder vertex in the red zone) and may be attributed to the formation of more hydration products (i.e., calcium-silicate-hydrate) [60-63]. For example, Belem and Benzaazoua reported an increase in UCS from 1000 to $2500 \mathrm{kPa}$ in CPB after 56 days of curing when the binder $(80 \%$ artificial pozzolan $+20 \%$ cement) content was increased from 3 to $6 \mathrm{wt} . \%$ [41].

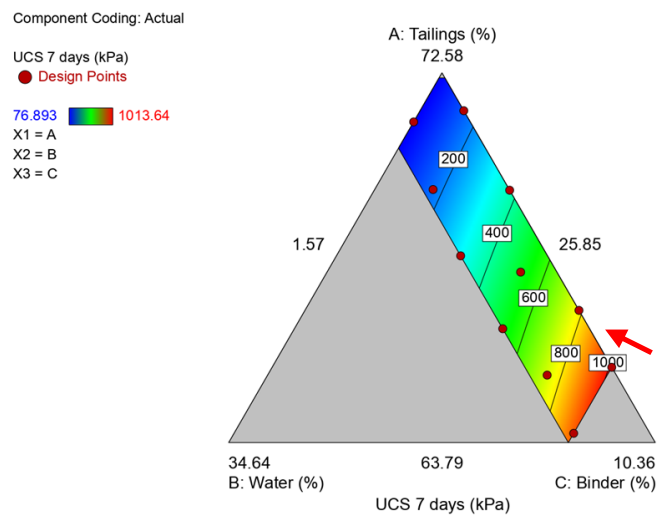

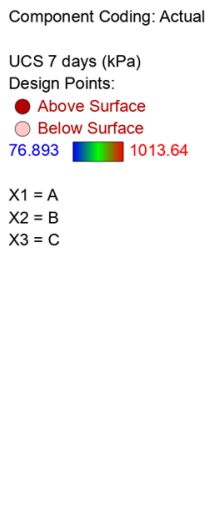

(a)

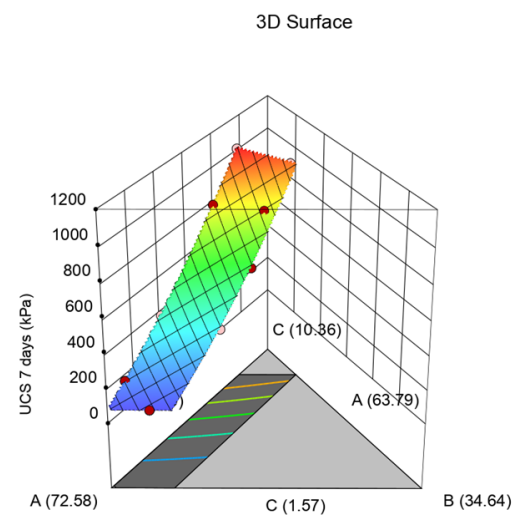

Figure 5. Cont. 

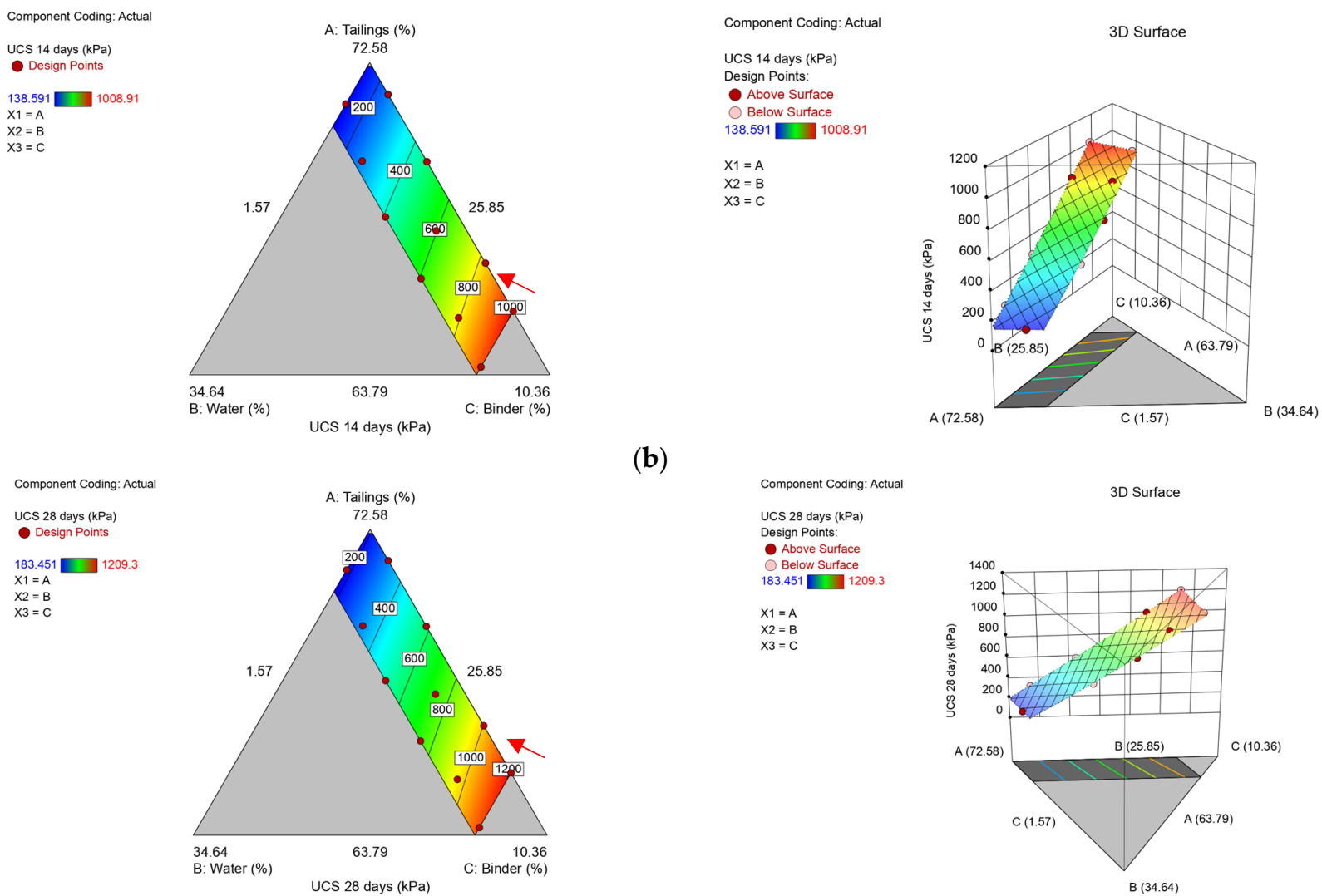

(b)
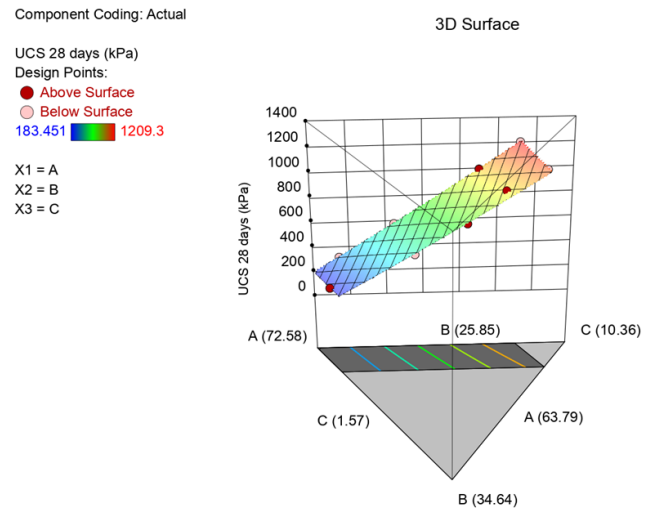

Component Coding: Actual UCS 56 days (kPa) $219.504 \square 1631.69$ $X_{1}=A$
$x_{2}=B$ $x_{2}=\mathrm{B}$
$x_{3}=0$

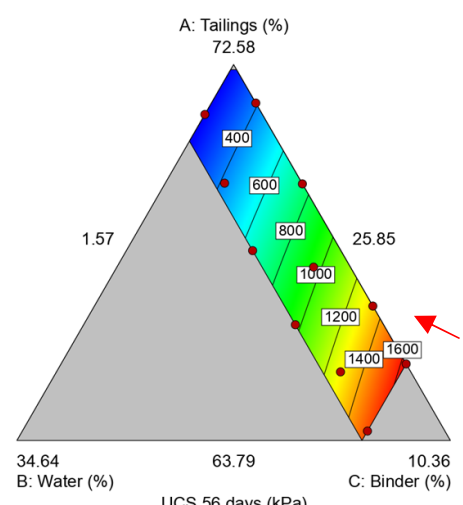

(c)
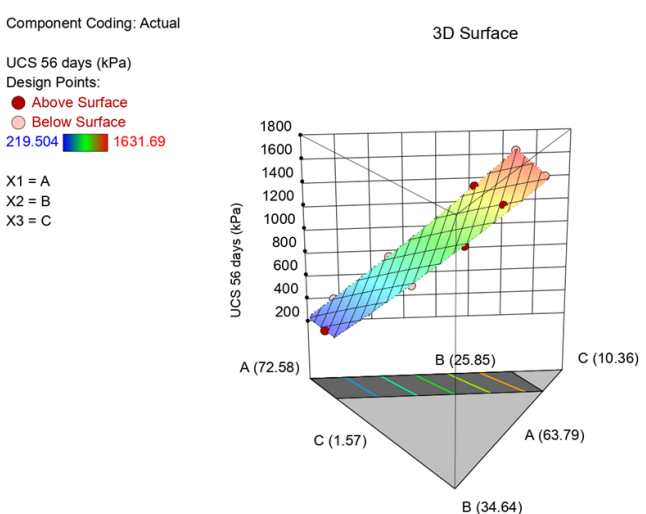

Component Coding: Actual UCS 90 days $(\mathrm{KPa})$
Design Points $286.324 \square 2084.38$ $X_{1}=A$
$x_{2}=B$

$x 2=B$
$x 3=C$

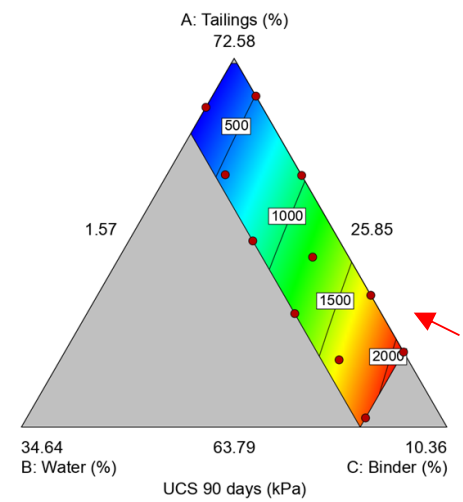

(d)

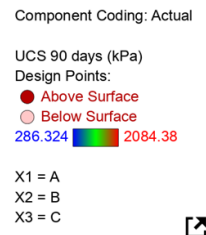

(e)

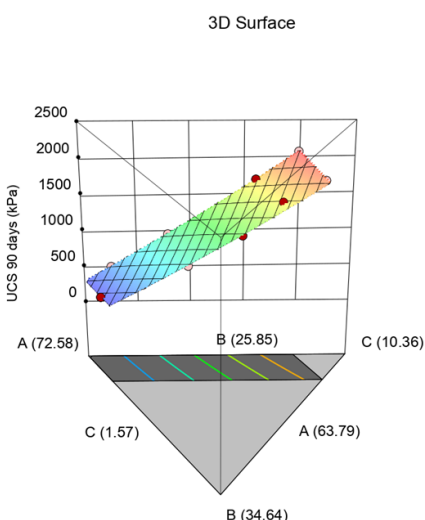

Figure 5. Model output of unconfined compressive strength (UCS) of cemented paste backfill prepared with PPC1 and cured for: (a) 7 days, (b) 14 days, (c) 28 days, (d) 56 days, and (e) 90 days. 
The UCS tended to decrease with increasing water content, but the UCS that was achieved for a given water content depended on the relative tailings and binder contents, as well as the curing time. At 56 curing days (Figure 5d) and at a constant water content, a range of UCS values was achieved (from 400 to $>1650 \mathrm{kPa}$ ), depending on the relative proportion of tailings and binder. This can be visualized by the line parallel to AC (tailingsbinder) and moving towards vertex B (water) passing through different color zones. Thus, more than one component influenced the UCS. Other scholars have reported the significant effect of water-to-binder ratio (w/b) on the UCS of CPB [54]. Random forest modeling by Liu et al. also showed that the UCS of CPB is highly influenced by the solids-to-water ratio in addition to the tailings-to-binder ratio, curing time, percent fines in tailings, and binder type [64].

The UCS increased with curing time. At a binder content of $7.2 \%$ and after 7 days of curing, the UCS was $784.4 \mathrm{kPa}$ (red arrow in Figure 5a). Increasing the curing time to 14, 28, 56 , and 90 days increased the UCS to 828.6, 1003, 1337, and $1712 \mathrm{kPa}$, respectively. These results are typical for $\mathrm{CPB}$ and are in agreement with Benzaazoua et al. who reported a protracted curing period of $>1$ month [65]. The slow reaction between the pozzolan and calcium hydroxide generated during cement hydration results in a low heat of hydration and a slow rate of strength development. The equations for pozzolanic reactions are well established in the literature [61].

Based on the descriptive models in Figure 5, five predictive models (Equations (5) (9)) were developed using the optimal mixture design approach and show that all three ingredients, as well as the interactions among them, have significant effects. For example, Equation (5) indicates that, after seven curing days, binder content $(\mathrm{C})$ has a strong positive effect on UCS and tailings (A), water (B), and the interactions between tailings and water $(\mathrm{AB})$, tailings and binder $(\mathrm{AC})$, and water and binder (BC) negatively affect the UCS. In all other models, the only single factor to have a positive effect on UCS for the entire curing period is binder content $(\mathrm{C})$. This factor is highest in the 7-day model, less than half that value in the 14- and 28-day models, and higher again at 56 and 90 days. Thus, the binder plays an important role in UCS development early and late in the curing period. The tailings-water interaction (AB) is also positive in Equations (5)-(9) but of a very low magnitude relative to the binder alone.

$$
\begin{gathered}
\mathrm{UCS}_{7 \text { days }}(\mathrm{kPa})=-10.18 \mathrm{~A}-39.63 \mathrm{~B}+882.78 \mathrm{C}+0.90 \mathrm{AB}-6.25 \mathrm{AC}-12.96 \mathrm{BC} \\
\mathrm{UCS}_{14 \text { days }}(\mathrm{kPa})=-5.13 \mathrm{~A}-27.08 \mathrm{~B}+410.95 \mathrm{C}+0.55 \mathrm{AB}-1.74 \mathrm{AC}-6.45 \mathrm{BC} \\
\mathrm{UCS}_{28 \text { days }}(\mathrm{kPa})=-1.62 \mathrm{~A}-3.75 \mathrm{~B}+404.87 \mathrm{C}+0.10 \mathrm{AB}-1.22 \mathrm{AC}-6.96 \mathrm{BC} \\
\mathrm{UCS}_{56 \text { days }}(\mathrm{kPa})=-9.42 \mathrm{~A}-50.72 \mathrm{~B}+689.94 \mathrm{C}+1.02 \mathrm{AB}-3.06 \mathrm{AC}-10.69 \mathrm{BC} \\
\mathrm{UCS}_{90 \text { days }}(\mathrm{kPa})=-10.60 \mathrm{~A}-55.94 \mathrm{~B}+849.02 \mathrm{C}+1.13 \mathrm{AB}-3.59 \mathrm{AC}-13.34 \mathrm{BC}
\end{gathered}
$$

where A, B, and C are tailings, water, and binder content, respectively (wt.\%).

The analysis of variance statistics for the PPC1 UCS models show that all predictive models are significant $(p<0.05)$ with high coefficients of determination (Table 7$)$.

The descriptive models for CPB samples prepared with PPC2 based on the experimental compositions in Table 6 show a similar trend to PPC1 (Figure 6). However, UCS development in the first 7 days was not as rapid (Figure 6a), and the maximum UCS after 90 curing days was lower for PPC2 (1517 kPa; Figure 6e) than PPC1 (vs. 2084 kPa; Figure 5e). Differences in the maximum UCS have been attributed to differing mineralogical and chemical composition, specific surface area, and structure (amorphous vs. crystalline) of the pozzolans [66]. The $\mathrm{CaO}$ content, for example, is critical to initiate hydration and strength development [67]. Since PPC1 contains more CaO (55.43\%) than PPC2 (49.42\%, Table 4), a higher UCS was achieved. Moreover, a higher pozzolan-specific surface area will increase the reaction area and improve reactivity and thus enhance UCS [66]. Again, PPC1 has a higher specific surface area $\left(3710 \mathrm{~cm}^{2} / \mathrm{g}\right)$ than PPC2 $\left(3300 \mathrm{~cm}^{2} / \mathrm{g}\right)$. 
Table 7. Statistics for analysis of variance for unconfined compressive strength models for cemented paste backfill samples prepared with PPC1 and cured for five time periods.

\begin{tabular}{cccccc}
\hline Model & 7 Day & 14 Day & 28 Day & 56 Day & 90 Day \\
\hline $\mathrm{R}^{2}$ & 1.00 & 1.00 & 1.00 & 1.00 & 1.00 \\
Adjusted $\mathrm{R}^{2}$ & 0.99 & 1.00 & 1.00 & 1.00 & 1.00 \\
Predicted $\mathrm{R}^{2}$ & 0.99 & 0.99 & 1.00 & 0.99 & 0.99 \\
$p$ value & $<0.0001$ & $<0.0001$ & $<0.0001$ & $<0.0001$ & $<0.0001$ \\
F value & $2.313 \times 10^{4}$ & $1.002 \times 10^{5}$ & $2.347 \times 10^{5}$ & $8.813 \times 10^{4}$ & $1.002 \times 10^{5}$ \\
CV\% & 0.5887 & 0.2311 & 0.1449 & 0.2485 & 0.2311 \\
Standard deviation & 3.00 & 1.32 & 1.02 & 2.29 & 2.73 \\
PRESS & 247.69 & 50.42 & 30.09 & 150.78 & 215.22 \\
\hline
\end{tabular}

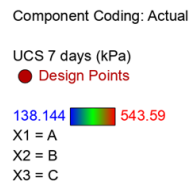

Component Coding: Actual UCS 14 days $(\mathrm{kPa})$ $220.392 \square 784.97$ $X_{1}=A$
$x_{2}=B$ $\mathrm{X} 2=\mathrm{B}$
$\mathrm{X} 3=\mathrm{C}$

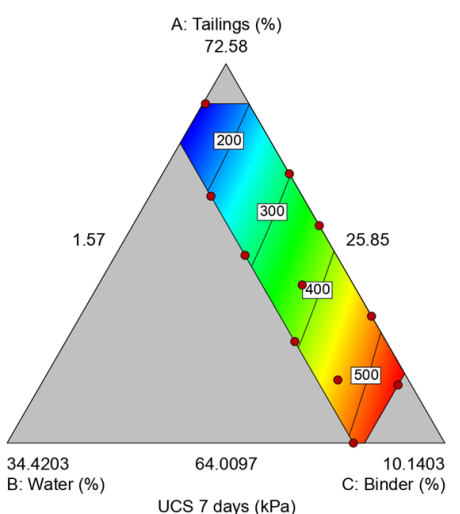

(a)

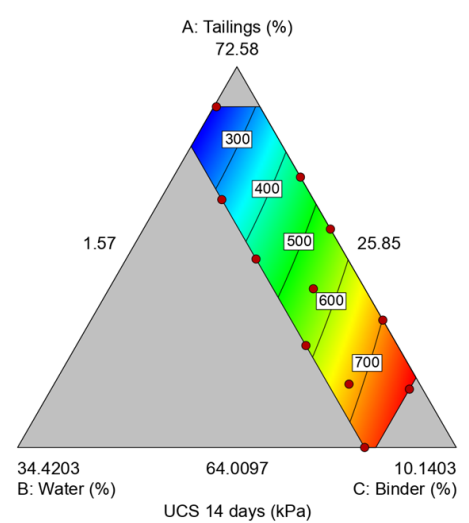

Component Coding: Actual UCS 28 days ( $\mathrm{kPa}$ ) 279.666$X_{1}=A$
$X_{2}=B$
$X_{3}=C$ $X_{1}=A$
$X_{2}=B$

[ᄌ

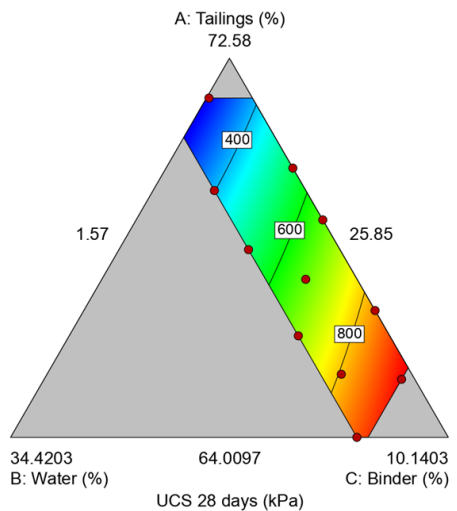

(b)
Component Coding: Actual

UCS 7 days (kPa) Design Points: - Above Surface Below Surface $X_{1}=A$

$X 2=B$
$X 3=C$ UCS 14 days ( $\mathrm{kPa}$ ) Design Points: - Above Surface Below Surface

$\mathrm{X}_{1}=\mathrm{A}$

$X_{1}=A$
$X_{2}=B$
$X_{3}=C$

UCS 28 days $(\mathrm{kPa})$ Design Points:

- Above Surface
Below Surface

Below Surface

$X_{1}=A$
$X_{2}=B$
$X_{3}=C$

$\mathrm{X} 3=\mathrm{C}$

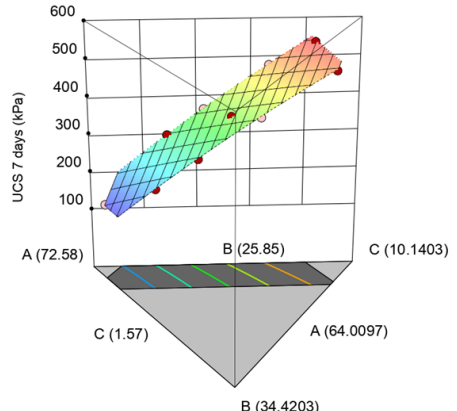

3D Surface

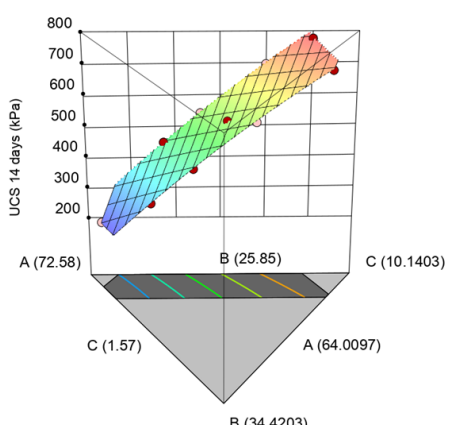

3D Surface

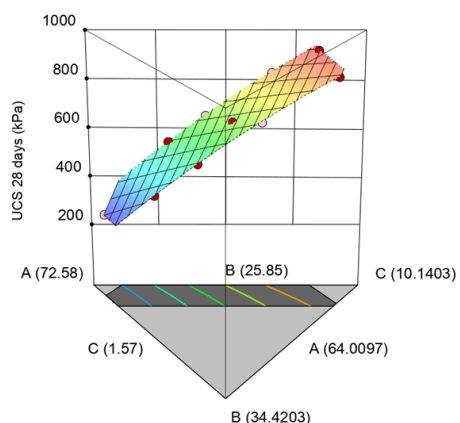

(c)

Figure 6. Cont. 


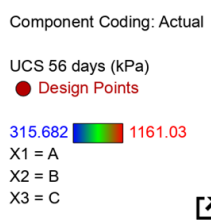

$[\pi$

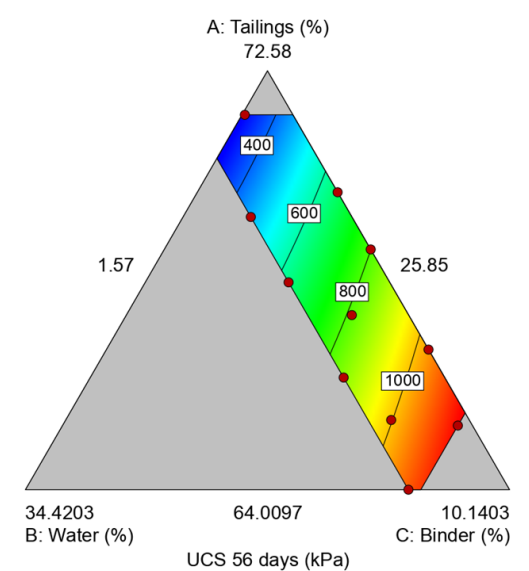

(d)
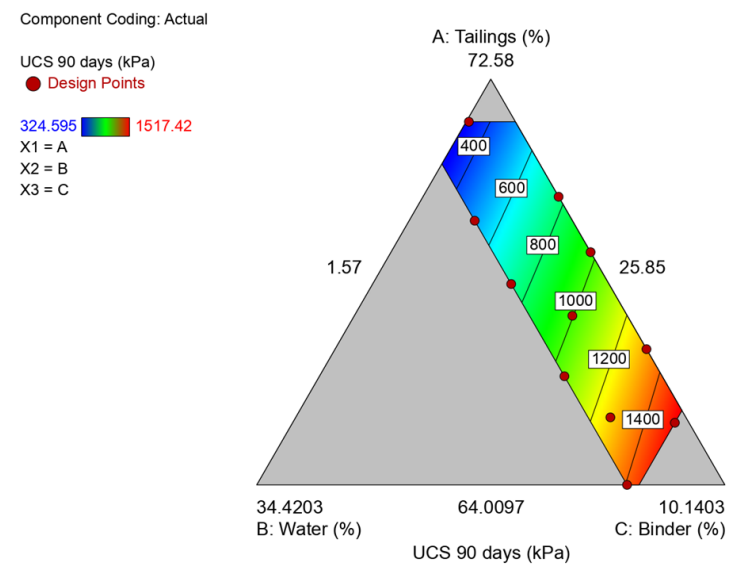

(e)
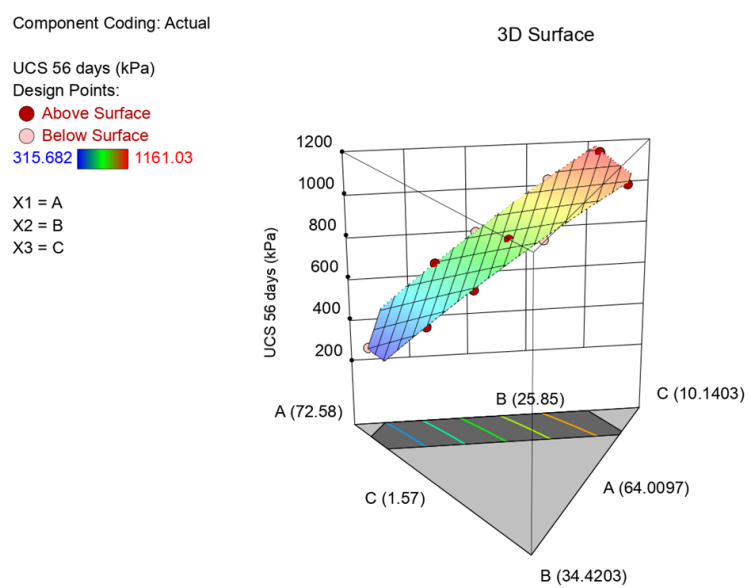

Component Coding: Actual

UCS 90 days $(\mathrm{kPa})$ Design Points:

- Above Surface

324.595 1517.42

$\mathrm{X} 1=\mathrm{A}$

$X 1=A$
$X 2=B$

$\mathrm{X}_{3}=\mathrm{C}$

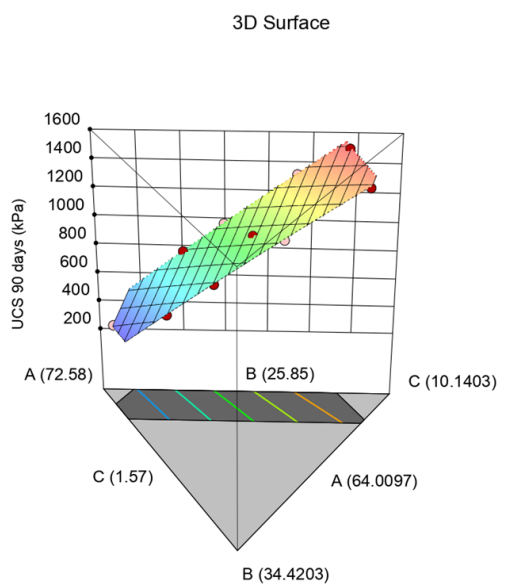

Figure 6. Model output of unconfined compressive strength of cemented paste backfill prepared with PPC2 and cured for: (a) 7 days, (b) 14 days, (c) 28 days, (d) 56 days, and (e) 90 days.

Predictive models for CPB samples made with PPC2 also indicate that the three ingredients and their interactions are significant factors (Equations (10)-(14)). However, unlike samples made with PPC1, factors A (tailings) and B (water) have a positive effect on UCS for all curing periods, and parameter C (binder) is only positive in the 7- and 90-day models. Similar to the PPC1 models, binder plays an important role in UCS development early and late in the curing period for $\mathrm{CPB}$ made with $\mathrm{PPC} 2$, but, as noted above, a relatively low $\mathrm{CaO}$ content and specific surface area diminish this role. Unlike the PPC1 models, the tailings-water $(\mathrm{AB})$ interaction effect is negative and the tailings-binder $(\mathrm{AC})$ interaction effect is positive. The water-binder (BC) interaction effects are negative in both PPC1 and PPC2 models.

$$
\begin{gathered}
\mathrm{UCS}_{7 \text { days }}(\mathrm{kPa})=13.85 \mathrm{~A}+98.42 \mathrm{~B}+17.58 \mathrm{C}-1.85 \mathrm{AB}+1.12 \mathrm{AC}-2.51 \mathrm{BC} \\
\mathrm{UCS}_{14 \text { days }}(\mathrm{kPa})=24.98 \mathrm{~A}+177.34 \mathrm{~B}-17.22 \mathrm{C}-3.32 \mathrm{AB}+2.05 \mathrm{AC}-3.64 \mathrm{BC} \\
\mathrm{UCS}_{28 \text { days }}(\mathrm{kPa})=33.70 \mathrm{~A}+239.24 \mathrm{~B}-54 \mathrm{C}-4.48 \mathrm{AB}+2.76 \mathrm{AC}-4.35 \mathrm{BC} \\
\mathrm{UCS}_{56 \text { days }}(\mathrm{kPa})=34.58 \mathrm{~A}+245.54 \mathrm{~B}-5.79 \mathrm{C}-4.60 \mathrm{AB}+2.83 \mathrm{AC}-5.37 \mathrm{BC} \\
\mathrm{UCS}_{90 \text { days }}(\mathrm{kPa})=22.3 \mathrm{~A}+159.40 \mathrm{~B}+207.31 \mathrm{C}-2.99 \mathrm{AB}+1.50 \mathrm{AC}-7.22 \mathrm{BC}
\end{gathered}
$$

where A, B, and C are tailings, water, and binder contents, respectively (wt.\%).

The analysis of variance statistics for the PPC2 UCS models show that all predictive models are significant with high coefficients of determination (Table 8). 
Table 8. Statistics for analysis of variance for unconfined compressive strength models for cemented paste backfill samples prepared with PPC2 and cured for five time periods.

\begin{tabular}{cccccc}
\hline Model & 7 Day & 14 Day & 28 Day & 56 Day & 90 Day \\
\hline $\mathrm{R}^{2}$ & 1.00 & 0.99 & 0.99 & 1.00 & 1.00 \\
Adjusted $\mathrm{R}^{2}$ & 0.99 & 0.99 & 0.99 & 0.99 & 1.00 \\
Predicted $\mathrm{R}^{2}$ & 0.99 & 0.99 & 0.99 & 0.99 & 1.00 \\
$p$ value & $<0.0001$ & $<0.0001$ & $<0.0001$ & $<0.0001$ & $<0.0001$ \\
F value & $3.512 \times 10^{4}$ & $1.792 \times 10^{4}$ & $1.197 \times 10^{4}$ & $2.187 \times 10^{4}$ & $2.298 \times 10^{5}$ \\
CV\% & 0.2609 & 0.3429 & 0.3992 & 0.3170 & 0.1125 \\
Standard deviation & 0.9625 & 1.87 & 2.62 & 2.54 & 1.11 \\
PRESS & 48.97 & 184.88 & 361.57 & 340.41 & 65.37 \\
\hline
\end{tabular}

\subsection{Effect of Water-to-Binder Ratio on UCS}

The predictive models for the CPB samples prepared with PPC1 (Equations (5)-(9)) and PPC2 (Equations (10)-(14)) were used to predict the UCS based on $\mathrm{w} / \mathrm{b}$ ratio for each curing day. For both binders and on each curing day, the UCS decreased with increasing $\mathrm{w} / \mathrm{b}$ ratio (Figure 7). This is expected because the water in excess of that needed for cement hydration evaporates with time, leaving capillary pores that increase the porosity and weaken the CPB $[54,68]$. The regression equations have high coefficients of determination; therefore, it is possible to accurately predict the UCS for a given CPB and curing time based on the $\mathrm{w} / \mathrm{b}$ ratio. The relationship between the UCS and $\mathrm{w} / \mathrm{b}$ ratio typically follows a power function, as has been observed in other studies $[69,70]$. A power factor of approximately -0.7 was reported for cemented aggregate tailings where the aggregate size varied from 50 to $150 \mathrm{~mm}$ [70]. In another study, a power factor of approximately -2 was obtained where the tailings were finer $\left(D_{50}\right.$ from 20 to $\left.500 \mu \mathrm{m}\right)$ [69]. Our results for CPB made with fine tailings ( $\mathrm{D}_{50}$ of $37 \mu \mathrm{m}$; Table 1 ) agree with these findings: the power factor for PPC1 ranged from approximately -1 to -1.5 (Figure $7 \mathrm{a}$ ), and for PPC2, it ranged from -0.7 to -1 (Figure $7 b)$.

(a)

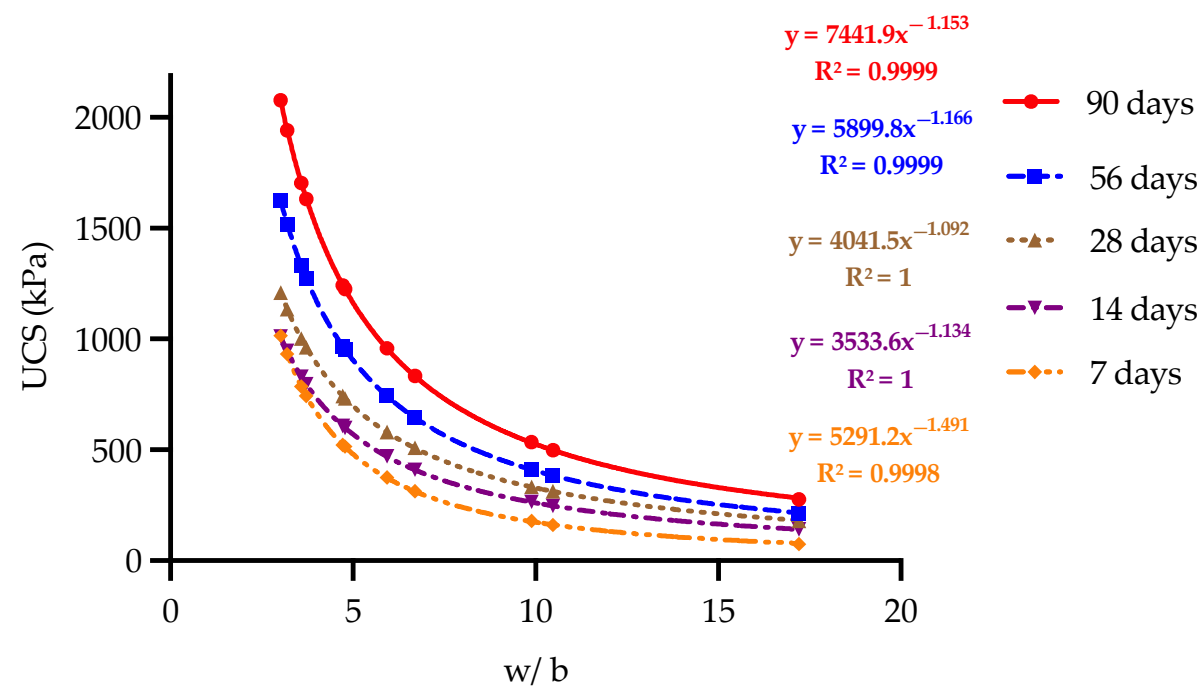

Figure 7. Cont. 
(b)

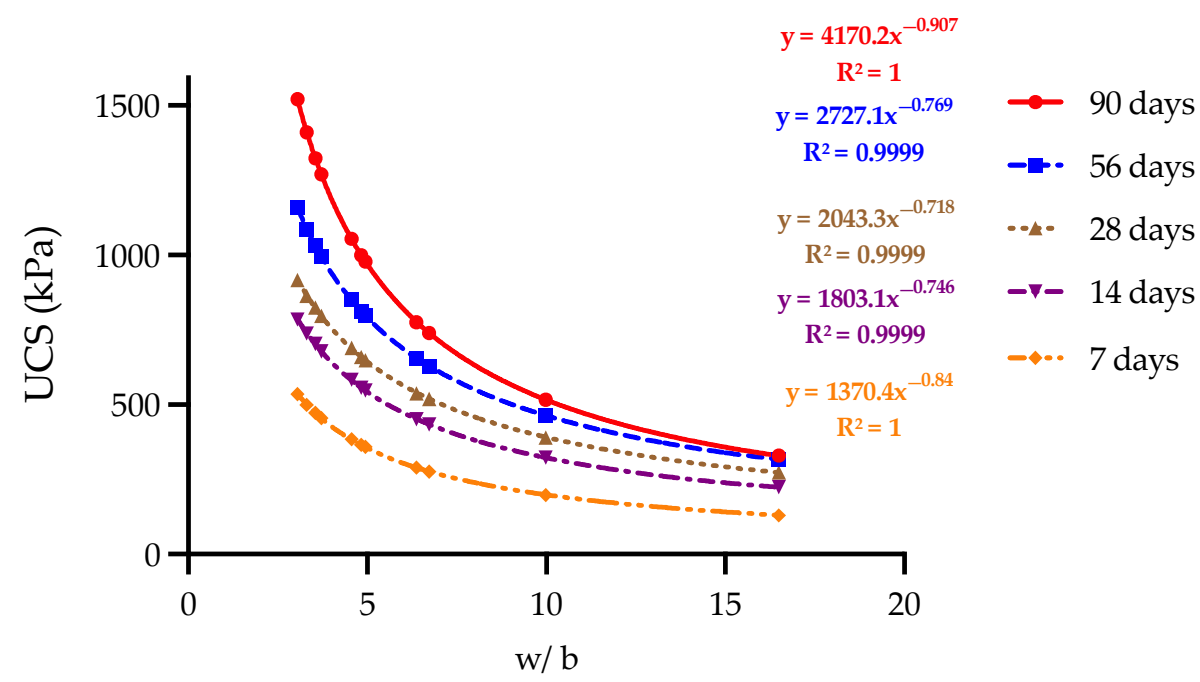

Figure 7. Relationship between unconfined compressive strength (UCS) and water-to-binder ratio $(\mathrm{w} / \mathrm{b})$ of cemented paste backfill samples prepared with binders (a) PPC1 and (b) PPC2.

\section{Policy Implications}

The new Saudi mining executive regulations issued in January 2021 have been revised to align with international best practices and to promote investment in mining projects within Saudi Arabia. They include an entire chapter dedicated to mine sustainability, which has four sections. Below, we describe how our findings fit within the revised regulations.

1. Environment: the re-use of tailings in backfilling applications will support the implementation of clean mining technology to manage mine tailings in such a way as to protect the environment and to minimize the storage of tailings on the surface.

2. Mine closure: the practice of mine backfilling is a part of progressive rehabilitation, which will not only facilitate closure, but also reduce closure costs and ensure sustainable land use after closure.

3. Occupational health and safety: the implementation of backfill technology will help to reduce the number of accidents associated with the storage of tailings on the surface and enhance the safety of the working environment. For example, backfill technology implemented in a Chinese coal mine resolved issues related to surface subsidence caused by underground mining activities [71].

4. Social responsibility: the Saudi regulations require applicants for a mining license to conduct an environmental and social impact study. Mine backfilling with tailings will minimize the negative impacts on surrounding communities who are directly affected by mining activities.

\section{Conclusions}

It is expected that the number of mining projects in Saudi Arabia will dramatically increase over the next decade, as will the production of associated mining waste. It is critical that this waste is managed to achieve sustainability in the mining sector and meet regulatory requirements. The study provides an example of how mine tailings can be used as an ingredient in backfill to reduce the need to buy or import backfill materials and minimize cement production and consumption. Given that CPB technology is relatively new in Saudi Arabia, this study highlights its importance in the context of sustainable mining. The following points can be concluded from the study:

1. The statistical design of the experiments was effective for developing models to predict backfill UCS as a function of tailings, water, and binder content and interactions among these factors. 
2. The UCS values for CPB increased with curing time. The maximum UCS after 90 days depended on CPB composition. UCS development (and possible degradation) after 90 days should be a focus of future studies.

3. The pozzolanic cement used as a binder affected the maximum UCS achieved. Future research is encouraged to investigate other environmentally friendly binders that could improve the mechanical properties of the CPB and lower operational costs.

4. The selected Saudi copper tailings can be used in mine backfill: the CPB samples developed UCS typical for CPB ( $<2 \mathrm{MPa})$, making them useful for various purposes (e.g., cut and fill mining and free-standing applications).

5. These bench-scale experimental results are promising for the use of selected copper tailings in mine backfill. However, field trials are required to demonstrate their application to an operational setting.

6. Microstructural studies are encouraged to better understand the effect of different recipes at the microscopic level, for example, using scanning electron microscopy.

7. In Saudi Arabia, the number of mines and range of target minerals is expected to increase to achieve the Saudi 2030 vision. Therefore, future research should also focus on the re-use of other tailings (e.g., gold tailings) for mine backfilling.

8. Mine backfilling can contribute to complying with regulatory requirements in Saudi Arabia and promote sustainability in the mining sector. It is a practical method to minimize the environmental damage caused by the surface disposal of mine tailings, especially those containing sulfide-bearing minerals.

9. Site-specific quantitative and qualitative (expert opinion) techno-economic assessments addressing technical, technological, economic, social, and environmental factors (per [22]) should be conducted for all stages of new and existing mine operations prior to the implementation of mine backfilling or other techniques.

Author Contributions: Supervision, M.H.; conceptualization, M.H. and H.A.M.A.; experimental design, M.H. and H.A.M.A.; sample preparation and testing, E.S.O.; data analysis, M.H., H.A.M.A., E.S.O. and M.A.A.; results and discussion, M.H., H.A.M.A. and M.A.A.; paper writing, M.H., H.A.M.A. and M.A.A. All authors have read and agreed to the published version of the manuscript.

Funding: This project was supported by the Deanship of Scientific Research (DSR), King Abdulaziz University, Jeddah, under Grant No. G:196-135-1442. The authors, therefore, gratefully acknowledge the DSR for technical and financial support.

Institutional Review Board Statement: Not applicable.

Informed Consent Statement: Not applicable.

Data Availability Statement: The data reported in this study are available within the manuscript.

Acknowledgments: The authors would also like to thank the anonymous reviewers who provided their constructive comments to improve the overall quality of the paper.

Conflicts of Interest: The authors declare no conflict of interest.

\section{References}

1. Schoenberger, E. Environmentally sustainable mining: The case of tailings storage facilities. Resour. Policy 2016, 49, 119-128. [CrossRef]

2. Wang, C.; Harbottle, D.; Liu, Q.; Xu, Z. Current state of fine mineral tailings treatment: A critical review on theory and practice. Miner. Eng. 2014, 58, 113-131. [CrossRef]

3. Qi, C.; Fourie, A.; Chen, Q.; Tang, X.; Zhang, Q.; Gao, R. Data-driven modelling of the flocculation process on mineral processing tailings treatment. J. Clean. Prod. 2018, 196, 505-516. [CrossRef]

4. Wang, S.; Zhao, Y.; Li, S.; Wei, Z. Improvement of traditional mining tailings storage facilities. J. Residuals Sci. Technol. 2016, 13, S11-S14. [CrossRef]

5. Araya, N.; Kraslawski, A.; Cisternas, L.A. Towards mine tailings valorization: Recovery of critical materials from Chilean mine tailings. J. Clean. Prod. 2019, 263, 121555. [CrossRef]

6. Kinnunen, P.H.M.; Kaksonen, A.H. Towards circular economy in mining: Opportunities and bottlenecks for tailings valorization. J. Clean. Prod. 2019, 228, 153-160. [CrossRef] 
7. Kinnunen, P.; Obenaus-Emler, R.; Raatikainen, J.; Guignot, S.; Guimerà, J.; Ciroth, A.; Heiskanen, K. Review of closed water loops with ore sorting and tailings valorisation for a more sustainable mining industry. J. Clean. Prod. 2021, 278, 123237. [CrossRef]

8. Bellenfant, G.; Guezennec, A.-G.; Bodenan, F.; D’Hugues, P.; Cassard, D. Reprocessing of mining waste: Combining environmental management and metal recovery? In Proceedings of the Eighth International Seminar on Mine Closure, Cornwall, UK, 18-20 September 2013. [CrossRef]

9. Edraki, M.; Baumgartl, T.; Manlapig, E.; Bradshaw, D.; Franks, D.M.; Moran, C.J. Designing mine tailings for better environmental, social and economic outcomes: A review of alternative approaches. J. Clean. Prod. 2014, 84, 411-420. [CrossRef]

10. Carneiro, A.; Fourie, A. Assessing the impacts of uncertain future closure costs when evaluating strategies for tailings management. J. Clean. Prod. 2020, 247, 119173. [CrossRef]

11. Mamelkina, M.A.; Heraiz-Carboné, M.; Cotillas, S.; Lacasa, E.; Sáez, C.; Tuunila, R.; Sillanpää, M.; Häkkinen, A.; Rodrigo, M.A. Treatment of mining wastewater polluted with cyanide by coagulation processes: A mechanistic study. Sep. Purif. Technol. 2020, 237, 116345. [CrossRef]

12. Skorohodov, V.; Nikitin, R.; Biryukov, V.; Kitaev, A. A mining-industrial waste water treatment technology: Justification of parametres using computer simulation. In Proceedings of the International Multidisciplinary Scientific GeoConference Surveying, Geology and Mining, Ecology and Management, SGEM, Albena, Bulgaria, 16-25 August 2020. [CrossRef]

13. Modoi, O.C.; Roba, C.; Török, Z.; Ozunu, A. Environmental risks due to heavy metal pollution of water resulted from mining wastes in NW Romania. Environ. Eng. Manag. J. 2014, 13, 2325-2336. [CrossRef]

14. Adiansyah, J.S.; Rosano, M.; Vink, S.; Keir, G. A framework for a sustainable approach to mine tailings management: Disposal strategies. J. Clean. Prod. 2015, 108, 1050-1062. [CrossRef]

15. Taha, Y.; Benzaazoua, M. Editorial for special issue 'Towards a sustainable management of mine wastes: Reprocessing, reuse, revalorization, and repository. Minerals 2020, 10, 21. [CrossRef]

16. Pličanič, S.; Mladenović, A.; Pranjić, A.M.; Vrhovnik, P. Mining waste in circular economy-Legislative aspect. Geol. Maced. 2020, 34, 149-156. [CrossRef]

17. Breitenbach, A.J. Overview: Tailings disposal and dam construction practices in the 21 st century. In Proceedings of the Tailings and Mine Waste'10-14th International Conference on Tailings and Mine Waste, Vail, CO, USA, 17-20 October 2010.

18. Fourie, A. Preventing catastrophic failures and mitigating environmental impacts of tailings storage facilities. Procedia Earth Planet. Sci. 2009, 1, 1067-1071. [CrossRef]

19. Oberle, B.; Brereton, D.; Mihaylova, A. Towards Zero Harm: A Compendium of Papers Prepared for the Global Tailings Review; GRID-Arendal: Arendal, Norway, 2020.

20. Lottermoser, B.G. Mine Wastes Characterization, Treatment and Environmental Impacts, 2nd ed.; Springer: New York, NY, USA; Berlin/Heidelberg, Germany, 2007.

21. Songolo, M.; Moono, W.S.; Mwenya, W.M. Achieving Sustainable Mine Waste Management Practices through Capacity Building of Stakeholder Engagement the Case of the Zambian Minerals Industry. Am. Sci. Res. J. Eng. Technol. Sci. 2016, $26,39-51$.

22. Rakhmangulov, A.; Burmistrov, K.; Osintsev, N. Sustainable open pit mining and technical systems: Concept, principles, and indicators. Sustainability 2021, 13, 1101. [CrossRef]

23. Segura-Salazar, J.; Tavares, L.M. Sustainability in the minerals industry: Seeking a consensus on its meaning. Sustainability 2018, 10, 1429. [CrossRef]

24. D'Adamo, I.; Lupi, G. Sustainability and resilience after COVID-19: A circular premium in the fashion industry. Sustainability 2021, 13, 1861. [CrossRef]

25. Lottermoser, B.G. Mine Wastes: Characterization, Treatment and Environmental Impacts, 3rd ed.; Springer: New York, NY, USA, 2010.

26. Karaoglu, K.; Yilmaz, E. Cemented paste backfill pressure monitoring and field testing. In Paste Tailings Management; Springer: Cham, Switzerland, 2017.

27. Yilmaz, E.; Kesimal, A.; Erçikdi, B. The factors affecting strength and stability of paste backfill I Macun doglu dayanimini ve durayliliğini etkileyen faktörler. Yerbilimleri Bull. Earth Sci. 2003, 28, 155-169.

28. Panchal, S.; Deb, D.; Sreenivas, T. Mill tailings based composites as paste backfill in mines of U-bearing dolomitic limestone ore. J. Rock Mech. Geotech. Eng. 2018, 10, 310-322. [CrossRef]

29. Ercikdi, B.; Külekci, G.; Yilmaz, T. Utilization of granulated marble wastes and waste bricks as mineral admixture in cemented paste backfill of sulphide-rich tailings. Constr. Build. Mater. 2015, 93, 573-583. [CrossRef]

30. Cihangir, F.; Ercikdi, B.; Kesimal, A.; Deveci, H.; Erdemir, F. Paste backfill of high-sulphide mill tailings using alkali-activated blast furnace slag: Effect of activator nature, concentration and slag properties. Miner. Eng. 2015, 83, 117-127. [CrossRef]

31. Hefni, M.A. The potential use of pumice in mine backfill. Exp. Results 2020, 1, e56. [CrossRef]

32. Ercikdi, B.; Cihangir, F.; Kesimal, A.; Deveci, H.; Alp, İ. Effect of natural pozzolans as mineral admixture on the performance of cemented-paste backfill of sulphide-rich tailings. Waste Manag. Res. 2010, 28, 430-435. [CrossRef] [PubMed]

33. Cao, S.; Yilmaz, E.; Song, W. Evaluation of viscosity, strength and microstructural properties of cemented tailings backfill. Minerals 2018, 8, 352. [CrossRef]

34. Yilmaz, E.; Yilmaz, E. Sustainability and Tailings Management in the Mining Industry: Paste Technology. Mugla J. Sci. Technol. 2018, 4, 16-26. [CrossRef]

35. Yilmaz, E.; Fall, M. Paste Tailings Management; Springer: Cham, Switzerland, 2017; ISBN 9783319396828. 
36. Tayebi-Khorami, M.; Edraki, M.; Corder, G.; Golev, A. Re-thinking mining waste through an integrative approach led by circular economy aspirations. Minerals 2019, 9, 286. [CrossRef]

37. Gayana, B.C.; Chandar, K.R. Sustainable use of mine waste and tailings with suitable admixture as aggregates in concrete pavements-A review. Adv. Concr. Constr. 2018, 6, 221-243. [CrossRef]

38. Hirschi, J.C.; Chugh, Y.P. Sustainable coal waste disposal practices. In Advances in Productive, Safe, and Responsible Coal Mining; Woodhead: Cambridge, UK, 2018.

39. Ivannikov, A.L.; Kongar-Syuryun, C.; Rybak, J.; Tyulyaeva, Y. The reuse of mining and construction waste for backfill as one of the sustainable activities. In IOP Conference Series: Earth and Environmental Science; IOP Publishing: Bristol, UK, 2019 ; Volume 362. [CrossRef]

40. Tariq, A.; Yanful, E.K. A review of binders used in cemented paste tailings for underground and surface disposal practices. J. Environ. Manag. 2013, 131, 138-149. [CrossRef]

41. Belem, T.; Benzaazoua, M. Design and application of underground mine paste backfill technology. Geotech. Geol. Eng. 2008, 26, 147-174. [CrossRef]

42. Benzaazoua, M.; Belem, T.; Bussière, B. Chemical factors that influence the performance of mine sulphidic paste backfill. Cem. Concr. Res. 2002, 32, 1133-1144. [CrossRef]

43. Hefni, M.; Ali, M.A. The Potential to Replace Cement with Nano-Calcium Carbonate and Natural Pozzolans in Cemented Mine Backfill. Adv. Civ. Eng. 2021, 2021, 5574761. [CrossRef]

44. Eshun, S.N.; Gidigasu, S.S.R.; Gawu, S.K.Y. The Effect of Clay Pozzolana-Cement-Composite on the Strength Development of a Hydraulic Backfill. Ghana Min. J. 2018, 18, 32-38. [CrossRef]

45. Rosca, E.; Arnold, M.; Bendul, J.C. Business models for sustainable innovation-An empirical analysis of frugal products and services. J. Clean. Prod. 2017, 162, S133-S145. [CrossRef]

46. Sivakugan, N.; Rankine, R.M.; Rankine, K.J.; Rankine, K.S. Geotechnical considerations in mine backfilling in Australia. J. Clean. Prod. 2006, 14, 1168-1175. [CrossRef]

47. Niroshan, N.; Sivakugan, N.; Veenstra, R.L. Laboratory Study on Strength Development in Cemented Paste Backfills. J. Mater. Civ. Eng. 2017, 29, 04017027. [CrossRef]

48. Kesimal, A.; Yilmaz, E.; Ercikdi, B. Evaluation of paste backfill mixtures consisting of sulphide-rich mill tailings and varying cement contents. Cem. Concr. Res. 2004, 34, 1817-1822. [CrossRef]

49. Hemalatha, T.; Ramaswamy, A. A review on fly ash characteristics-Towards promoting high volume utilization in developing sustainable concrete. J. Clean. Prod. 2017, 147, 546-559. [CrossRef]

50. McLellan, B.C.; Williams, R.P.; Lay, J.; van Riessen, A.; Corder, G.D. Costs and carbon emissions for geopolymer pastes in comparison to ordinary portland cement. J. Clean. Prod. 2011, 19, 1080-1090. [CrossRef]

51. Mehta, P.K. High-performance, high-volume fly ash concrete for sustainable development. In Proceedings of the International Workshop on Sustainable Development and Concrete Technology, Beijing, China, 20-21 May 2004.

52. Yang, K.H.; Jung, Y.B.; Cho, M.S.; Tae, S.H. Effect of supplementary cementitious materials on reduction of $\mathrm{CO}_{2}$ emissions from concrete. J. Clean. Prod. 2015, 103, 774-783. [CrossRef]

53. Hefni, M.; Hassani, F. Effect of air entrainment on cemented mine backfill properties: Analysis based on response surface methodology. Minerals 2021, 11, 81. [CrossRef]

54. Fall, M.; Benzaazoua, M.; Saa, E.G. Mix proportioning of underground cemented tailings backfill. Tunn. Undergr. Sp. Technol. 2008, 23, 80-90. [CrossRef]

55. Jiang, H.; Qi, Z.; Yilmaz, E.; Han, J.; Qiu, J.; Dong, C. Effectiveness of alkali-activated slag as alternative binder on workability and early age compressive strength of cemented paste backfills. Constr. Build. Mater. 2019, 218, 689-700. [CrossRef]

56. Fall, M.; Célestin, J.C.; Pokharel, M.; Touré, M. A contribution to understanding the effects of curing temperature on the mechanical properties of mine cemented tailings backfill. Eng. Geol. 2010, 114, 397-413. [CrossRef]

57. Wu, A.; Wang, Y.; Wang, H.; Yin, S.; Miao, X. Coupled effects of cement type and water quality on the properties of cemented paste backfill. Int. J. Miner. Process. 2015, 143, 65-71. [CrossRef]

58. Mahlaba, J.S.; Kearsley, E.P.; Kruger, R.A.; Pretorius, P.C. Evaluation of workability and strength development of fly ash pastes prepared with industrial brines rich in so $4=$ and Cl- to expand brine utilisation. Miner. Eng. 2011, 24, 1077-1081. [CrossRef]

59. ASTM International. ASTM D2166/D2166M-16, Standard Test Method for Unconfined Compressive Strength of Cohesive Soil; ASTM International: West Conshohocken, PA, USA, 2016.

60. Hassani, F.; Archibald, J. Mine Backfill; Canadian Institute of Mining, Metallurgy and Petroleum: Montreal, QC, Canada, 1998.

61. Mehta, P.K.; Monteiro, P.J.M. Concrete: Microstructure, Properties, and Materials, 4th ed.; McGraw-Hill Education: New York, NY, USA, 2014. Available online: https://www.accessengineeringlibrary.com/content/book/9780071797870 (accessed on 18 May 2021).

62. Potvin, Y.; Thomas, E.; Fourie, A. Handbook on Mine Fill; Australian Centre for Geomechanics: Nedlands, Western Australia, Australia, 2005.

63. Mehta, P.K.; Monteiro, P.J.M. Third Edition Prentice; Hall, Inc.: Englewood Cliffs, NJ, USA, 2006.

64. Liu, J.; Li, G.; Yang, S.; Huang, J. Prediction models for evaluating the strength of cemented paste backfill: A comparative study. Minerals 2020, 10, 1041. [CrossRef] 
65. Benzaazoua, M.; Peyronnard, O.; Belem, T.; Stephant, A.; Dublet, G. Key issues related to behaviour of binders in cemented paste backfilling. In Proceedings of the Thirteenth International Seminar on Paste and Thickened Tailings, Perth, Australia, 5-7 May 2010. [CrossRef]

66. Walker, R.; Pavía, S. Physical properties and reactivity of pozzolans, and their influence on the properties of lime-pozzolan pastes. Mater. Struct. Constr. 2011, 44, 1139-1150. [CrossRef]

67. Mahedi, M.; Cetin, B.; White, D.J. Cement, Lime, and Fly Ashes in Stabilizing Expansive Soils: Performance Evaluation and Comparison. J. Mater. Civ. Eng. 2020, 32, 04020177. [CrossRef]

68. Amaratunga, L.M.; Yaschyshyn, D.N. Development of a high modulus paste fill using fine gold mill tailings. Geotech. Geol. Eng. 1997, 15, 205-219. [CrossRef]

69. Cheng, H.; Wu, S.; Zhang, X.; Li, J. A Novel Prediction Model of Strength of Paste Backfill Prepared from Waste-Unclassified Tailings. Adv. Mater. Sci. Eng. 2019, 2019. [CrossRef]

70. Salvoldi, B.; van der Spuy, B.; Wilson, S. Optimisation of cemented aggregate backfill at New Luika Gold Mine. In Proceedings of the 22nd International Conference on Paste, Thickened and Filtered Tailings, Cape Town, South Africa, 8-10 May 2019. [CrossRef]

71. Chang, Q.; Chen, J.; Zhou, H.; Bai, J. Implementation of paste backfill mining technology in Chinese coal mines. Sci. World J. 2014, 2014. [CrossRef] [PubMed] 